ORIGINAL ARTICLE / ARTIGO ORIGINAL

\title{
Prevalence of congenital anomalies at birth among live births in the state of Maranhão from 2001 to 2016: temporal and spatial analysis
}

\author{
Prevalências a nascimento de anomalias congênitas entre nascidos vivos no \\ estado do Maranhão de 2001 a 2016: análise temporal e espacial
}

\author{
Luzivan Costa Reis' (D), Márcia Helena Barbian" (D), Augusto César Cardoso-dos-Santos ',111 (D), \\ Elis Vanessa de Lima Silva' (D), Juliano André Boquett',IV (D), Lavínia Schuler-Faccinil,I,v, (D)
}

\begin{abstract}
Objectives: To analyze the prevalence at birth and the spatial and temporal distribution of congenital anomalies (CAs) among live births in the state of Maranhão in 2001 to 2016. To describe demographic, gestational and neonatal variables of interest. Methods: Ecological, population-based study, using secondary data from the Live Birth Information System (SINASC). Annual prevalence of total and per-group CAs was calculated. Spatial analyzes were based on the Local Indicators of Spatial Association (LISA) and the Moran I Index, and interactive maps were generated. Demographic, gestational and neonatal variables of interest available from SINASC were described in the group of newborns with CAs. Results: $1,831,830$ live births, 6,110 with CAs $(33.4 / 10,000)$ were included. Higher frequencies occurred in more recent years. Spatial clusters have been observed in specific years. The prevalence of newborns with CAs was different between categories of variables considered as risk factors for this outcome. Conclusion: The prevalence at birth of total CAs was lower than expected for major human defects (3\%). The temporal peak of records in 2015/2016 is probably related to the increase in CAs caused by gestational infection by the Zika virus. The spatial clusters were probably due to variations at random due to the small number of births as they are not repeated in other years. Studies like this are the basis for the establishment of CA surveillance programs.
\end{abstract}

Keywords: Congenital abnormalities. Ecological studies. Live birth. Teratogenic dangers.

'Postgraduate Program in Genetics and Molecular Biology, Department of Genetics, Universidade Federal do Rio Grande do Sul Porto Alegre (RS), Brazil.

"Institute of Mathematics and Statistics, Universidade Federal do Rio Grande do Sul - Porto Alegre (RS), Brazil.

"'Health Surveillance Secretariat, Ministry of Health - Brasília (DF), Brazil.

IvPostgraduate Program in Child and Adolescent Health, Universidade Federal do Rio Grande do Sul - Porto Alegre (RS), Brazil. vMedical Genetics Service, Hospital de Clínicas de Porto Alegre, National Institute of Medical Genetics - Porto Alegre (RS), Brazil. Corresponding author: Lavínia Schuler-Faccini. Departamento de Genética, Universidade Federal do Rio Grande do Sul. Avenida Bento Gonçalves, 95.000, CEP: 91501-970, Campus do Vale, Porto Alegre, RS, Brasil. E-mail: lavinia.faccini@ufrgs.br

Conflict of interest: nothing to declare - Financial support: Coordination for the Improvement of Higher Education Personnel, Brazil (CAPES), process 88882.345626/2019-01. 
RESUMO: Objetivos: Analisar as prevalências ao nascimento e a distribuição espacial e temporal das anomalias congênitas (ACs) entre nascidos vivos no estado do Maranhão nos anos de 2001 a 2016; descrever variáves de interesse demográficas, gestacionais e neonatais. Métodos: Estudo ecológico, de base populacional, a partir de dados secundários do Sistema de Informações sobre Nascidos Vivos (SINASC). Foram calculadas prevalências ao nascimento anuais de ACs totais e por grupos. Análises espaciais utilizaram o cálculo de Indicadores Locais de Associação Espacial (LISA) e o Índice Global de Moran I, e mapas interativos foram gerados. Variáveis de interesse demográficos, gestacionais e neonatais disponíveis no SINASC foram descritas no grupo dos recém-nascidos com ACs. Resultados: Neste estudo, foram incluídos 1.831 .830 nascidos vivos, $6.110 \mathrm{com}$ ACs (33,4/10 mil). Maiores frequências ocorreram nos anos mais recentes. Aglomerados espaciais foram observados em anos específicos. As prevalências de nascidos vivos com anomalias foram diferentes entre categorias de variáveis consideradas como fatores de risco para esse desfecho. Conclusão: A prevalência ao nascimento de nascidos com ACs foi inferior ao esperado para defeitos maiores na espécie humana (3\%). O pico temporal de registros em 2015/2016 está provavelmente relacionado ao aumento de microcefalia causada pela infecção gestacional por vírus Zika. Os aglomerados espaciais provavelmente se deveram a variações ao acaso pelo número pequeno de nascimentos, pois não se repetem em outros anos. Estudos como este são base para o estabelecimento de programas de vigilância de defeitos congênitos.

Palavras-chave: Anomalias congênitas. Estudos ecológicos. Nascimento vivo. Perigos teratogênicos.

\section{INTRODUCTION}

Congenital anomalies (ACs) are changes that occur in the embryonic processes and are present at birth ${ }^{1}$, due to genetic or environmental factors, or their combination ${ }^{2}$. Some factors may increase the likelihood of its incidence, such as inbreeding, maternal age, congenital infections (Zika virus, rubella), chronic maternal diseases (pre-gestational diabetes, epilepsy) and the use of medications during pregnancy (thalidomide, misoprostol $)^{2,3}$. Worldwide, 2 to $3 \%$ of all live births are estimated to present some clinically significant morphological abnormality (major anomalies) ${ }^{4}$, many of which are preventable at different levels ${ }^{1,5}$.

CAs are an important component of infant mortality in Latin America and the Caribbean, being the second leading cause of death of children under the age of five ${ }^{6}$. In Brazil, They are the second cause of infant mortality, behind prematurity only ${ }^{7}$, with ocurrence in $2.71 /$ thousand children under one year of age between 2006 and $2010^{8}$.

There are several studies showing the frequencies of CAs in different regions of Brazil, but in specific States of the North and Northeast regions these analyses are still scarce ${ }^{9}$. The State of Maranhão, for example, is exposed to risk situations such as the endemic presence of the Zika vírus, the high prevalence of leprosy and consequent use of thalidomide ${ }^{10}$, the inbreeding rate higher than the overall Brazil average ${ }^{11}$, and the possible low intake of folic acid by women in reproductive age ${ }^{12}$. The elaboration of baseline frequencies of CAs at birth is an important step for the establishment of an active surveillance program that allows the rapid identification of new teratogens in the environment. Thus, the objective of 
this study was to analyze the prevalence of CAs at birth, as well as the spatial and temporal distribution in live births. As secondary objective, we also aimed to describe the variables of interest associated with CAs in the State of Maranhão from 2001 to 2016.

\section{METHODS}

The information was collected from public data made available online by the Ministry of Health of Brazil, through the Informatics Department of the Unified Health System (DATASUS). The data come from the Live Birth Information System (SINASC), the Unified Health System (SUS), whose source is the Statement of Live Births (SLB), a mandatory document in Brazil ${ }^{13}$. In addition to gestational, birth and demographic data, there is also a field for notification of CAs observed at birth. From the verbatim description of the anomalies in the SLB, a second step involves coding according to chapter XVII (Congenital Malformations Q00-Q99) of the Tenth Revision of the International Statistical Classification of Diseases and Related Health Problems (ICD-10) ${ }^{14}$. In the public area of SINASC, CAs are grouped, just like the other maternal and newborn variables.

The study population included all live births from 2001 and 2016, children of women residing in the State of Maranhão. Subsequently, all records in which the "Congenital Anomaly" field was included as "ignored" were excluded from the analysis. The data were consulted in the year 2018. This work has an ecological design, since the analytical units represent population groups (the municipality being the level of greatest analytical breakdown).

The prevalence of CAs at birth in live births was calculated by the numerator as the total number of children with a record of at least one CA from 2001 to 2016, while the denominator was the total live births in the same period, excluding the ones whose "Congenital Anomaly" field was marked as "ignored". Then, the prevalences were multiplied by 10,000 and their respective $95 \%$ confidence intervals $(95 \% \mathrm{CI})$ were calculated by the Poisson distribution ${ }^{15}$.

In this study, prevalence at birth was also calculated considering groups of diagnoses according to the ICD-10 provided by DATASUS. Prevalence ratios of newborns with CAs were calculated with respective $95 \% \mathrm{CI}$ in the following categories of variables:

- Maternal age ( $<35$ years or $\geq 35$ years);

- Number of prenatal consultations ( $<7$ or $\geq 7$ );

- Marital status (with or without a stable partner);

- Maternal education ( $<12$ years of study or $\geq 12$ years of study);

- Type of delivery (vaginal or cesarean);

- Type of pregnancy (single or twins and multiple);

- Prematurity ( $<37$ weeks or $\geq 37$ weeks);

- Sex (male or female);

- Skin color (white, black, brown or indigenous/yellow);

- Birth weight $(<2500 \mathrm{~g}$ or $\geq 3500 \mathrm{~g})$;

- 5-minute Apgar score ( $<8$ or $\geq 8)$. 
Spatial and temporal analyses were implemented in the software $\mathrm{R}$ version 3.6.0 under the RStudio interface. For the development of visualization tools, we used several R packages, of which shiny ${ }^{16}$ should be highlighted, for the development of web applications; ggplot, for the creation of graphics; and leaflet, for the creation of maps.

In order to measure the spatial autocorrelation between prevalences of municipalities, the Global Moran Index I ${ }^{17}$ was used. It assumes values in the range -1 to 1 , where zero indicates the null hypothesis that there is no spatial association between the áreas, and positive values suggest that nearby areas tend to be similar. If the Global Moran Index is positive and significant $(\mathrm{p}<0.05)$, municipalities are expected to be grouped in some way. One of the alternatives to identify these cases is to calculate the Local Indicators of Spatial Association (LISA) and spatial dependence at the local level (Anselin) ${ }^{18}$, which determine the individual contribution of each area to the calculation of the Global Moran Index and are useful statistics in the identification of areas of high prevalence, as well as clusters of municipalities with similar values for the prevalence of CAs.

Maps with the spatial distribution and time series of the prevalence of ACs in the different municipalities of Maranhão from 2001 to 2019 are available in two free-access applications in the following links: https: / mhbarbian.shinyapps.io/ AppAnomaliasCongenitasMaranhao1 / and https: / / mhbarbian.shinyapps.io/AppTiposAnomaliasCongenitasMaranhao2/. These two tools allow data to be viewed interactively; the user chooses different filters, such as year and type of anomaly, and these are presented in maps or time series. These applications are aimed at researchers and managers interested in understanding the spatial and spatio-temporal variations of CAs in the State of Maranhão, in addition to identifying high-risk areas and detecting possible clusters in specific regions.

Open, secondary and anonymized databases were used exclusively. Thus, the Project was not submitted to a Research Ethics Committee. However, this study was carried out in accordance with Resolution No. 466, of December 12, 2012, by the National Health Council, which governs research with human beings.

\section{RESULTS}

From 2001 to 2016, 1,934,958 live births were registered in the State of Maranhão. Of these, 6,110 were born with CAs and 103,128 (5\%) were excluded from the analysis, as the field of CAs in the registration was marked as "ignored". Thus, the total births considered in the denominator was $1,831,830$. The prevalence of CAs at birth was 33.4/ 10,000 (95\%CI, 29.3 - 37.4). There has been an increase in records over the years from $19.3 / 10,000$ in 2001 to $62.0 / 10,000$ in 2016 (Figure 1). In particular, 2015 and 2016 had the highest values.

Figure 2 shows differences between neighboring municipalities with agglomerations of CAs with high values of $I_{i}$ (Global Moran Index) in the West and South regions of the State, mainly in the cities close to Imperatriz and Davinópolis, and in the central region (municipality of Barra do Corda ), in 2008 and 2010. In the central region, the municipality 
of Governador Eugênio Barros had a low value of CAs' $I_{i}$ in relation to the neighbouring municipalities in 2016 (Figure 2D).

The most common CAs involved the musculoskeletal and the nervous systems (Table 1).

Table 2 shows different distributions of births of children with CA according to variables considered as "at risk". As for maternal characteristics, the highest prevalence occurred in women over the age of 35 years, among those who had more than seven prenatal consultations, who were married, with schooling above 12 years, cesarean delivery and twin pregnancy. ACs were more frequent among newborns with low birth weight, premature births and males.

\section{DISCUSSION}

In the series of years studied, there was an increase in the registration of CAs over the years, especially in 2015 / 2016. Other Brazilian studies also show that in 2016 there was an increase in notifications of CAs, due to the number of cases of congenital microcephaly caused by the Zika virus, in addition to a possible greater attention to congenital malformations

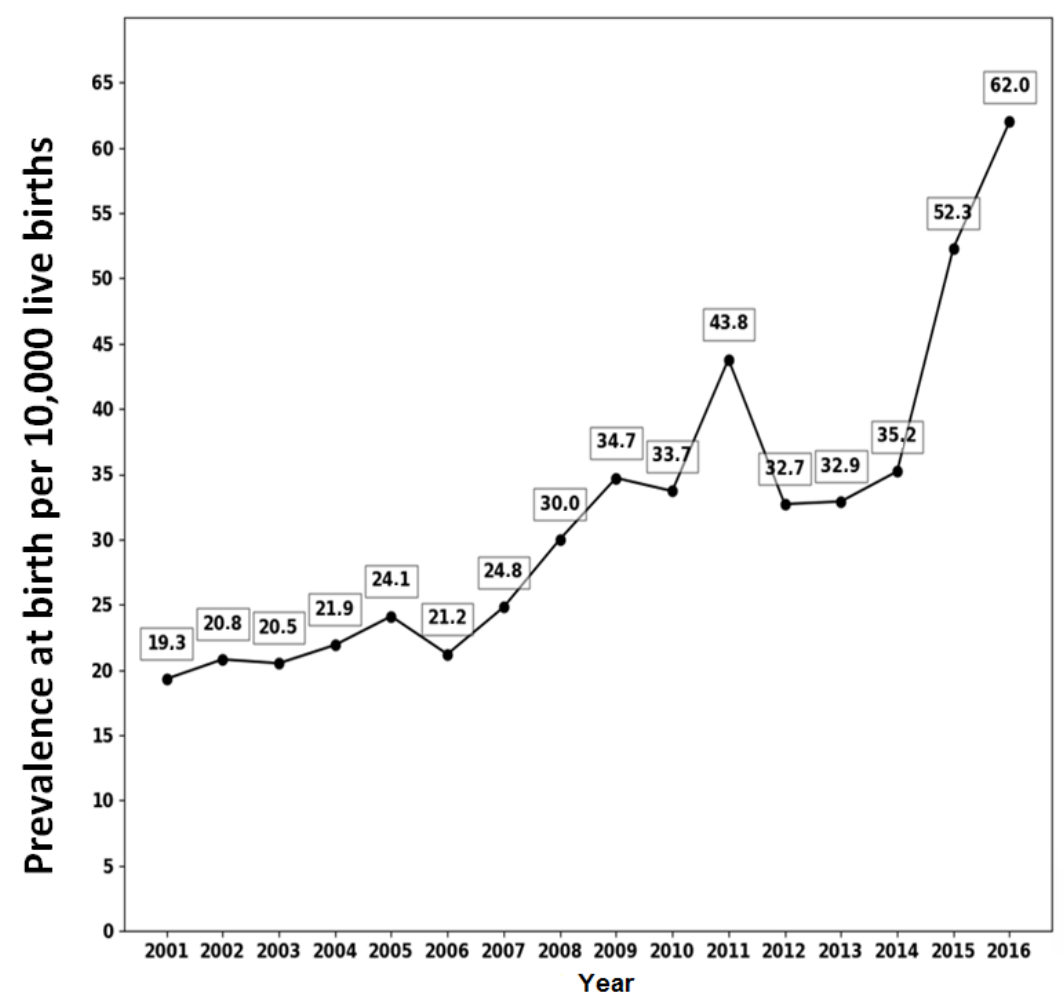

Source: Live Birth Information System (SINASC), 2019.

Figure 1. Temporal distribution of the prevalence of congenital anomalies in Maranhão, from 2001 to 2016. 
in general, also motivated by the teratogenicity of the Zika ${ }^{19}$ virus. As shown in Figure 1, there is a "leap" of notifications from the year 2015 on. Even so, the total prevalence over these 15 years of observation is around one tenth of the expected for the human species in general $(2-3 \%)^{4}$.

Part of this difference in relation to other international studies stems from the type of anomaly and even the quality of the record. For example, a study followed the evolution of the correct filling of birth defects in SLB in four maternity hospitals in the city of São Paulo in 2008, totaling 10,000 births. The authors then stated an increase in the notifications of defects in maternity hospitals in São Paulo, where the study was carried out, when

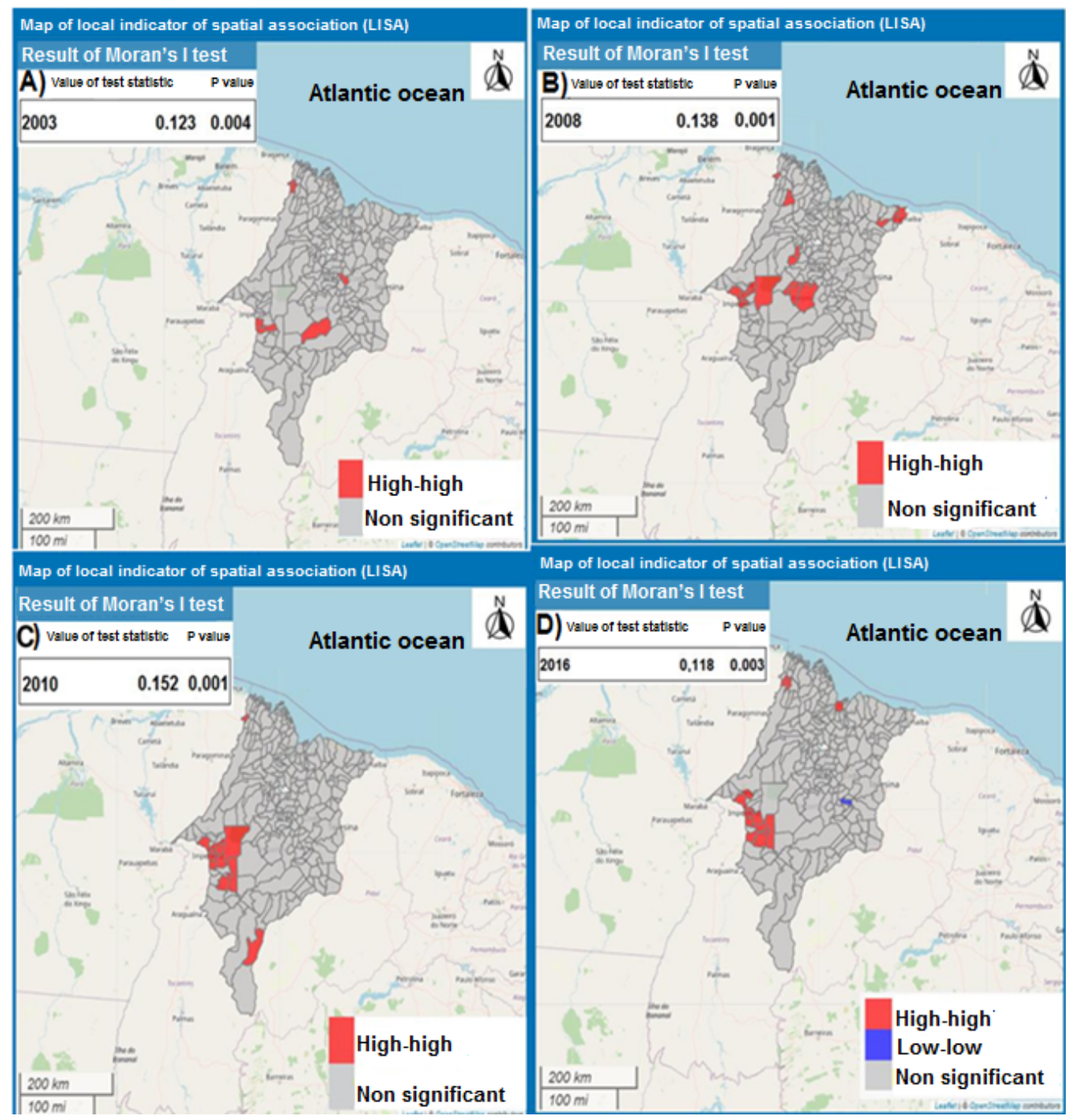

*The image shows only years with a significant LISA spatial correlation index (Moran li) for the period analyzed.

Figure 2. Analysis of geographical distribution of clusters of prevalence of live births with congenital anomalies in the State of Maranhão*. 
compared to previous years ${ }^{20}$. States such as São Paulo and Rio Grande do Sul, where there is a special awareness and training projects for professionals who describe and codify CAs, had higher prevalences than expected for the human species ${ }^{20}$.

One of the particularities that must be considered is the fact that the SLB is filled in immediately after birth, which allows, above all, that CAs easily visible at birth are diagnosed $^{9,13}$. This is observed in the present study, as well as in other studies in Brazil ${ }^{19,21,22}$, in which anomalies of the musculoskeletal system, secondary to anomalies of the central nervous system, are the most frequently recorded ${ }^{19,22-24}$. These abnormalities are easily identified in routine ultrasound during prenatal care or physical examination. In contrast, congenital heart disease appears much less in records that include only neonatal data, but are much higher when analyzing infant mortality records ${ }^{25}$. In Brazil, particularly from 2015, the records of nervous system CAs started receiving special attention during and after the Zika virus epidemic ${ }^{26}$.

The Latin American Collaborative Study of Congenital Malformations (ECLAMC) covers several Latin American countries and tends to have much higher prevalences than those observed in studies based on SINASC. However, ECLAMC has its own operating mode, of which we highlight the following:

Table 1. Prevalence of congenital anomalies by group available in the Live Birth Information System in the State of Maranhão, from 2001 to 2016, for every 10,000 live births.

\begin{tabular}{|c|c|c|}
\hline Classification of types of congenital anomalies & $\mathrm{n}$ & Prevalence $(95 \% \mathrm{Cl})$ \\
\hline Musculoskeletal system (Q65-Q79) & 1,680 & $8.7(7.6-10.4)$ \\
\hline Congenital foot deformities (Q66) & 1,072 & $5.5(3.3-7.7)$ \\
\hline Nervous system (Q00-Q07) & 1,004 & $5.2(3.0-7.4)$ \\
\hline Other congenital malformations (Q80-Q89) & 640 & $3.3(0.5-3.8)$ \\
\hline Cleft lip and palate (Q35-Q37) & 413 & $2.1(0.7-3.5)$ \\
\hline Digestive system (Q38-Q45) & 351 & $1.8(0.2-3.8)$ \\
\hline Urinary tract (Q60-Q64) & 348 & $1.7(0.3-3.7)$ \\
\hline Chromosomal abnormalities (Q90-Q99) & 245 & $1.3(1.2-3.8)$ \\
\hline Circulatory system (Q20-Q28) & 154 & $0.8(0.7-0.9)$ \\
\hline Spina bifida (Q05) & 138 & $0.7(0.6-0.8)$ \\
\hline Hemangioma and lymphangioma of any location (D18) & 25 & $0.1(0.1-0.2)$ \\
\hline Congenital hip deformities (Q65) & 18 & $0.1(0.0-0.1)$ \\
\hline Undescended testicle (Q53) & 8 & $0.0(0.0-0.0)$ \\
\hline Absence, atresia or stenosis of the small intestine (Q41) & 7 & $0.0(0.0-0.0)$ \\
\hline
\end{tabular}

95\% Cl: 95\% confidence interval.

Source: Live Birth Information System (SINASC), 2019 
Table 2. Prevalence of congenital anomalies according to variables of interest available in the Information System on Live Births in the State of Maranhão, from 2001 to 2016, for every 10,000 live births.

\section{Variables \\ Prevalence $(95 \% \mathrm{Cl}) \quad$ Prevalence ratio $(95 \% \mathrm{Cl}) \quad p$ value \\ $\mathrm{n}$}

Maternal age

$<35$ years

$\geq 35$ years

Pre-natal care

$0-6$ consultations

$\geq 7$ consultations

Marital status

No partner

Partner

Schooling

$$
0-11 \text { years }
$$

$\geq 12$ years

5,536

537

$32.1(27.5-36.6)$
$50.6(46.1-55.1)$

\begin{tabular}{|c|}
1.00 \\
$1.59(1.44-1.72)$ \\
\hline
\end{tabular}

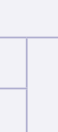

$<0.001$

Type of delivery

$$
\text { Vaginal }
$$

C-section

4,213

$32.6(31.8-33.2)$

1,834

$35.4(34.7-36.1)$
$0.91(0.87-0.97)$
1.00

0.027

\begin{tabular}{|c|c|}
$0.81(0.77-0.86)$ & $<0.001$ \\
1.00 &
\end{tabular}

\begin{tabular}{|l|l|}
\hline 3,390 & $30.7(28.8-32.4)$ \\
\hline 2,608 & $37.6(35.8-39.4)$ \\
\hline
\end{tabular}

$0.88(0.84-0.94)$

0.012

\begin{tabular}{|c|c|}
\hline 5,441 & $33.3(32.3-34.2)$ \\
\hline 537 & $37.3(36.4-38.2)$ \\
\hline
\end{tabular}

1.00

0.012

3,074

$24.9(17.2-23.5)$

$50.8(45.7-55.9)$

$\frac{1.00}{2.04(1.26-3.28)}$

$<0.001$
Type of pregnancy

Only one

Twins or multiples

Time of gestation

\begin{tabular}{|l|l|}
\hline$\leq 36$ weeks & 1,101 \\
\hline 36 weeks & 4,775 \\
\hline
\end{tabular}

Sex

Male

Female

\begin{tabular}{|c|c|c|c|c|}
\hline White & 718 & $31.5(20.4-42.6)$ & 1.00 & \\
\hline Black & 176 & $32.4(21.2-43.6)$ & $1.02(0.87-1.21)$ & 0.078 \\
\hline Brown & 4,285 & $30.9(19.8-42.0)$ & $0.97(0.90-1.06)$ & 0.621 \\
\hline Indigenous/yellow & 76 & $27.9(17.4-38.4)$ & $0.88(0.69-1.12)$ & 0.307 \\
\hline \multicolumn{5}{|l|}{ Birth weight } \\
\hline$<2500 \mathrm{~g}$ & 1,447 & $115.7(107.7-123.8)$ & $4.29(2.82-6.52)$ & \multirow{2}{*}{$<0.001$} \\
\hline$\geq 2500 \mathrm{~g}$ & 4,634 & $27.3(10.7-44.0)$ & 1.00 & \\
\hline \multicolumn{5}{|l|}{ 5-minute Apgar } \\
\hline $0-7$ & 1,175 & $156.6(146.8-166.4)$ & $4.90(3.35-7.16)$ & \multirow{2}{*}{$<0.001$} \\
\hline $8-10$ & 4,268 & $32.0(10.0-53.9)$ & 1.00 & \\
\hline Total & 6,110 & $33.4(29.3-37.4)$ & - & - \\
\hline
\end{tabular}

Ethnicity

95\% Cl: $95 \%$ confidence interval.

Source: Live Birth Information System (SINASC), 2019. 
- It was based on hospitals, many of which are tertiary, to which high-risk births with prenatal diagnosis of CAs are referred;

- The record of congenital malformations can be done up to the moment of hospital discharge by a professional trained for this purpose;

- There is a quality control system carried out by a coordinating center with data qualification when incomplete'.

Other studies on the prevalence of CAs at birth in Brazil show heterogeneous results, also with a upward trend in recent years - for example, in São Luiz, Maranhão (34/10 thousand in 2002 and $75 / 10$ thousand in 2011 $)^{22}$. Geographic differences between States are more striking, ranging from 20/10 thousand (Rio Branco, Acre) to 160/10 thousand (São Paulo) ${ }^{20-25,27-28}$.

The reasons for the geographic differences in prevalence both in Maranhão and in Brazil may be the consequences of population (genetic, ancestry) and environmental differences ${ }^{11,12,29}$, and should be further investigated. However, when they are put in clusters that occurred in specific years and do not repeat in later years, a possible explanation is that, in rare events and in small populations, the additional birth of a single child with CA can impact the frequency of the year in question.

Cardoso-dos-Santos et al. assessed spatial clusters of CAs in Maranhão, finding them isolated, mainly in the southern and central regions of Maranhão, in a study that used the analysis of surnames as a consanguinity marker ${ }^{11}$. Finding clusters or isolates can be a starting point to identify populations whose demographic characteristics can raise the presence of a genetic syndrome (so-called "genetic isolates") or identify a specific environmental teratogen ${ }^{30-32}$.

We draw attention to the positive associations between CAs and some studied variables available in SINASC, in agreement with the Brazilian and international literature , $^{3,12,21,30}$. Advanced maternal age and twinning are independent risk factors for the occurrence of chromosomal abnormalities, while other variables are possibly a consequence of malformative syndromes such as prematurity, low birth weight and low Apgar score ${ }^{30}$. Surprisingly, other variables considered to be protective, for example, maternal education, stable marital relationship and a higher number of prenatal consultations, had a high prevalence in registers of CAs (Table 2). One hypothesis for this finding would be that these women would have more access to health services and, possibly, a better diagnosis of anomalies ${ }^{30}$.

One of the limitations of this study was the use of secondary public data available in SINASC. The study was carried out with grouped and non-individualized data for newborns and CAs. Thus, more sophisticated analyses, looking for interactions between these variables as well as between variables by multivariate analysis, were not possible.

In conclusion, we recorded the baseline frequencies of CAs in Maranhão, showing an increase in records between 2001 and 2016. We also reported an association of CAs with some risk variables and the existence of spatial clusters of CAs in the southern and central regions of Maranhão. This study can serve as a basis for implementing protocols for active and prospective surveillance of these anomalies in the State of Maranhão. 


\section{REFERENCES}

1. Nacul LC, Stewart A, Alberg C, Chowdhury S, Darlison MW, Grollman C, et al. A Toolkit to assess health needs for congenital disorders in low- and middleincome countries: an instrument for public health action. J Pub Health 2014; 36(2): 243-50. https: / / doi. org/10.1093/pubmed/fdt048

2. Santos S, Kok F, Weller M, Paiva FRL, Otto PA. Inbreeding levels in Northeast Brazil: strategies for the prospecting of new genetic disorders. Genet $\mathrm{Mol}$ Biol 2010; 33(2): 220-3. https: // doi.org/10.1590/ S1415-47572010005000020

3. Mazzu-Nascimento T, Melo DG, Morbioli GG, Carrilho E, Vianna FSL, Silva AA, et al. Teratogens: a public health issue - a Brazilian overview. Genet Mol Biol 2017; 40(2): 387-97. https:// doi. org/10.1590/ 1678-4685-GMB-2016-0179

4. Moorthie S, Blencowe H, Darlison MW, Lawn DJ, Mastroiacovo P, Morris JK, et al. An overview of concepts and approaches used in estimating the burden of congenital disorders globally. J Community Genet 2018; 9(4): 347-62. https://doi.org/10.1007/ s12687-017-0335-3

5. Modell B, Darlison MW, Malherbe H, Moorthie S, Blencowe H, Mahaini R, et al. Congenital disorders: epidemiological methods for answering calls for action. J Community Genet 2018; 9(4): 335-40. https: / / doi. org/10.1007/s12687-018-0390-4

6. Zarante I, Hurtado-Villa P, Walani SR, Kancherla V, López Camelo J, Giugliani R, et al. A consensus statement on birth defects surveillance, prevention, and care in Latin America and the Caribbean. Rev Panam Salud Publica 2019; 43: e2. https: / / doi.org/10.26633/ RPSP.2019.2

7. Brasil. Saúde Brasil 2018: Uma análise da situação de saúde e das doenças e agravos crônicos: desafios e perspectivas. Brasil: Ministério da Saúde; 2019.

8. Bronberg R, Schuler-Faccini L, Ramallo V, Alfaro E, Dipierri J. Spatial and temporal analysis of infant mortality from congenital malformations in Brazil (1996-2010). J Community Genet 2014; 5(3): 269-82. https: / / doi.org/10.1007/s12687-013-0170-0

9. Luquetti DV, Koiffman RJ. Quality of birth defect reporting in the Brazilian Information System on Live Births (SINASC): a comparative study of 2004 and 2007. Cad Saúde Pública 2010; 26(9): 1756-65. https:// doi.org/10.1590/S0102-311X2010000900009

10. Vianna FSL, Kowalski TW, Fraga LR, Sanseverino MT, Schuler-Faccini L. The impact of thalidomide use in birth defects in Brazil. Eur J Med Genet 2017; 60(1): 12-5. https: / doi.org/10.1016/j.ejmg.2016.09.015
11. Cardoso-dos-Santos AC, Ramallo V, Zagonel-Oliveira M, Veronez MR, Navarro P, Monlleó IL, et al. An invincible memory: what surname analysis tells us about history, health and population medical genetics in the Brazilian Northeast. J Bio Science 2020; 1-16. https: / doi.org/10.1017/S0021932020000127

12. Schuler-Faccini L, Sanseverino MTV, Rocha-Azevedo LM, Moorthie S, Alberg C, Chowdhury S, et al. Health needs assessment for congenital anomalies in middleincome countries: Examining the case for neural tube defects in Brazil. J Community Genet 2014; 5(2): 147 55. https: / / doi.org/10.1007/s12687-013-0165-x

13. Brasil. Ministério da Saúde. Departamento de Informática do Sistema Único de Saúde - Sistema de Notificações sobre Nascidos Vivos [Internet]. Brasil: Ministério da Saúde; 2019 [acessado em 22 ago. 2019]. Disponível em: http: / / www2.datasus.gov.br/ DATASUS $/$ index.php? area $=0205 \& \mathrm{id}=6936$

14. Organização Mundial da Saúde. Classificação estatística internacional para doenças e problemas relacionados à saúde (CID-10). São Paulo: Centro colaborador da OMS para a Classificação das doenças em português; 2008. [acessado em 13 abr. 2019]. Disponível em: http:/ / www2. datasus.gov.br/DATASUS / index.php?area $=060203$

15. Bégaud B, Martin K, Abouelfath A, Tubert-Bitter P, Moore N, Moride Y. Any easy-to-use method for approximate Poisson confidence limits. Eur J Epidemiol 2005; 20(3): 213-6. https://doi.org/10.1007/ s10654-004-6517-4

16. Chang W, Cheng J, Allaire JJ, Xie Y, McPherson J. shiny: Web Application Framework for R. R package version 1.5.0 [Internet]. 2020 [acessado em 13 abr. 2019]. Disponível em: https: / CRAN.R-project.org/package=shiny

17. Bivand RS, Pebesma EJ, Gómez-Rubio V, Pebesma EJ. Applied spatial data analysis with R. Nova York: Springer; 2008. v. 747248717.

18. Anselin L. Local Indicators of Spatial Association LISA. Geo Analysis 1995; 27(2): 93-115. https:// doi. org/10.1111/j.1538-4632.1995.tb00338.x

19. Silva JH, Terças ACP, Pinheiro LCBP, França GVA, Atanaka M, Schüler-Faccini L. Perfil das anomalias congênitas em nascidos vivos de Tangará da Serra, Mato Grosso, 2006-2016. Epidemiol Serv Saúde 2018; 27(3): 1-10. https://doi.org/10.5123/s1679-49742018000300017

20. Nicola PDR, Cernach MCSP, Perez ABA, Brunoni D. A utilização da Internet na notificação dos defeitos congênitos na Declaração de Nascido Vivo em quatro maternidades públicas do Município de São Paulo, Brasil. Cad Saúde Pública 2010; 26(7): 1383-90. https: / / doi.org/10.1590/S0102-311X2010000700017 
21. Guimarães ALS, Barbosa CC, Oliveira CM, Maia LTS, Bonfim CV. Relationship of databases of live births and infant deaths for analysis of congenital malformations. Rev Bras Saude Mater Infant 2019; 19(4): 925-33. https:// doi. org/10.1590/1806-93042019000400010

22. Rodrigues LS, Lima RHS, Costa LC, Batista RFL. Características das crianças nascidas com malformações congênitas no município de São Luís, Maranhão, 2002-2011. Epidemiol Serv Saúde 2014; 23(2): 296-303. https: // doi.org/10.5123/ S1679-49742014000200011

23. Lima NA, Silva SMM, Santos MM, Fernandes TAM, Lucena EES. Perfil Epidemiológico das Malformações Congênitas em Recém-Nascidos no Estado do Rio Grande do Norte no Período de 2004 a 2011. Rev Bras Ciênc Saúde 2018; 22(1): 45-50. https: / / doi. org/10.4034/RBCS.2018.22.01.06

24. Cosme HW, Lima LS, Barbosa LG. Prevalência de Anomalias Congênitas e fatores associados em RecémNascidos do município de São Paulo no período de 2010 a 2014. Rev Paul Pediatr 2017; 35(1): 33-8. https: / / doi.org/10.1590/1984-0462/;2017;35;1;00002

25. Luz GG, Karam SM, Dumith SC. Anomalias congênitas no estado do Rio Grande do Sul: análise de série temporal. Rev Bras Epidemiol 2019; 22: e190040. https: / doi.org/10.1590/1980-549720190040

26. Marinho F, Araújo VEM, Porto DL, Ferreira HL, Coelho MRS, Lecca RCR, et al. Microcefalia no Brasil: prevalência e caracterização dos casos a partir do Sistema de Informações sobre Nascidos Vivos (SINASC), 2000-2015. Epidemiol Serv Saúde 2016; 25(4): 701-12. https://doi.org/10.5123/ s1679-49742016000400004

27. Reis AT, Santos RSS, Mendes TAR. Prevalência de malformações congênitas no município do Rio de Janeiro, Brasil, entre 2000 e 2006. Rev Enferm [Internet] 2011 [acessado em 19 abr. 2019]; 19(3): 364-8. Disponível em: http: / /www.arca.fiocruz.br/ handle/icict/9388
28. Freire MHS, Barros APMM, Andrade L, Nihei OK, Fontes KB. Geospatial analysis of births with congenital disorders, Paraná, 2008-2015: ecological study. Rev Bras Enferm 2020; 73(3): e20180741. https: / doi. org/10.1590/0034-7167-2018-0741

29. Lima LMM, Melo ACO, Vianna RPT, Moraes RM. Análise espacial das anomalias congênitas do sistema nervoso. Cad Saúde Colet 2019; 27(3): 257-63. https: / / doi.org/10.1590/1414-462x201900030313

30. Baldacci S, Gorini F, Santoro M, Pierini A, Minichilli F, Bianchi F. Environmental and individual exposure and the risk of congenital anomalies: a review of recent epidemiological evidence. Epidemiol Prev 2018; 42(3-4 Supl. 1): 1-34. https:// doi.org/10.19191/ ep18.3-4.s1.p001.057

31. Cardoso GC, de Oliveira MZ, Paixão-Côrtes VR, Castilla EE, Schuler-Faccini L. Clusters of genetic diseases in Brazil. J Community Genet 2019; 10(1): 121-8. https: / / doi.org/10.1007/s12687-018-0369-1

32. GiliJA, Poletta FA, Giménez LG, Pawluk MS, Campaña $\mathrm{H}$, Castilla EE, et al. Descriptive analysis of high birth prevalence rate geographical clusters of congenital anomalies in South America. Birth Defects Res A Clin Mol Teratol 2016; 106(4): 257-66. https: / / doi. org/10.1002/bdra.23481

Received on: 06/30/2020

Revised on: 12/06/2020

Accepted on: 12/07/2020

Preprint on: 12/17/2020

Authors' contribution: Luzivan C. R., Lavínia S. and Márcia H. B. participated in the design of the study, data collection, analysis and interpretation, and writing of the manuscript. Augusto C. C., Elis V. L. S. and Juliano A. B. participated in data analysis and interpretation, and writing of the manuscript. All authors participated in the critical analysis and approved the final version of the manuscript, being responsible for all aspects and ensuring its accuracy and integrity 